\title{
Sustainable Low-Carbon Development of Urban Public Transport: International and Russia's Experience
}

\author{
Olga V. Kudryavtseva*, Anastasiia V. Baraboshkina \\ and Artem K. Nadenenko \\ Lomonosov Moscow State University \\ Moscow, Russian Federation
}

Received 20.07.2021, received in revised form 10.09.2021, accepted 10.11.2021

\begin{abstract}
The rapid growth of cities all over the world has inevitably led to the aggravation of economic, social and environmental problems. In this regard, developing «green», low-carbon, circular and other new economic models is necessary. Transport sector is an important source of greenhouse gas emissions and air pollutants. The purpose of this work is to assess the impact of urban public transport, especially electric buses, on the air quality. The authors have analyzed international and Russia's experience of the lowcarbon development of urban public transport and evaluated the environmental effects of transitioning to electric buses in Moscow using a regression model and data visualization tools. The results have shown that integrating electric buses into an urban transport system can be considered as a step towards the low-carbon development of the transport sector. The authors have identified a decrease in carbon monoxide $(\mathrm{CO})$ pollution in the districts of Moscow where there are electric bus routes. Although the authors managed to demonstrate positive aspects of using e-buses instead of traditional ones, the proposed hypotheses were not fully confirmed due to limited data and a small number of electric bus routes at an early stage of the project. The results of the work can be used both in theoretical studies of sustainable development and practical implementation of programs for the low-carbon development of an urban transport network.
\end{abstract}

Keywords: low-carbon development, sustainable development, transport sector, air pollution, public transport, electric buses.

The research was supported by the intra-faculty grant of the Faculty of Economics of Lomonosov Moscow State University «Sustainable development of Russia's economy under the global low-carbon agenda: from the inter-industry model to industrial policy» (2021).

Research area: economics and national economy management (economics of environmental management).

(C) Siberian Federal University. All rights reserved

* Corresponding author E-mail address: olgakud@mail.ru 
Citation: Kudryavtseva, O.V., Baraboshkina, A.V., Nadenenko, A.K. (2021). Sustainable low-carbon development of urban public transport: international and russia's experience. J. Sib. Fed. Univ. Humanit. soc. sci., 14(12), 1795-1807. DOI: 10.17516/1997-1370-0859

\title{
Устойчивое низкоуглеродное развитие городского общественного транспорта: зарубежный и российский опыт
}

\author{
О.В. Кудрявцева, А.В. Барабошкина, А.К. Надененко \\ Московский государственный университет имени М. В. Ломоносова \\ Российская Федераџия, Москва
}

\begin{abstract}
Аннотация. Рост городов по всему миру неминуемо ведет к проблемам экономического, социального и экологического характера. Закономерно встает вопрос о формировании «зеленой», низкоуглеродной, циклической и других новых моделей экономики. Транспортная отрасль отвечает за значительное количество выбросов парниковых газов и загрязняющих веществ. Цель данной работы - оценка влияния общественного транспорта, в особенности электрических автобусов, на качество воздуха в городской среде. Авторы рассмотрели международный и российский опыт низкоуглеродного развития общественного транспорта и оценили экологические эффекты от внедрения электрических автобусов в г. Москве с помощью регрессионного анализа и инструментов визуализации данных. В результате было выявлено, что интеграцию электробусов в городскую транспортную систему можно назвать шагом к низкоуглеродному развитию транспортной отрасли. Авторы обнаружили значимое уменьшение среднемесячной концентрации угарного газа $(\mathrm{CO})$ в воздухе в районах курсирования электробусов в Москве, то есть удалось продемонстрировать позитивные аспекты использования электрических автобусов вместо традиционных. Однако недостаток данных и ранняя стадия реализации проекта экологизации общественного транспорта в Москве не позволили полностью подтвердить выдвинутые гипотезы. Данная тема имеет большой потенциал для дальнейшего исследования. Результаты работы могут быть использованы как в теоретических исследованиях, так и в практической разработке программ низкоуглеродного развития городского транспорта.
\end{abstract}

Ключевые слова: низкоуглеродное развитие, устойчивое развитие, транспортная отрасль, загрязнение воздуха, общественный транспорт, электробусы.

Исследование поддержано внутрифакультетским грантом экономического факультета МГУ 2021 г. «Устойчивое развитие российской экономики в рамках мировой низкоуглеродной повестки: от межотраслевой модели до промышленной политики».

Научная специальность: 08.00.05 - экономика и управление народным хозяйством. 


\section{Introduction}

Sustainable urban development was highlighted among the objectives of the world development strategy for the period up to 2030, adopted by the UN General Assembly in 2015 (United Nations, 2015). Among the 17 Sustainable Development Goals (SDGs) we should note Goal 9 «Build resilient infrastructure, promote inclusive and sustainable industrialization and foster innovation», Goal 11 «Make cities and human settlements inclusive, safe, resilient and sustainable», Goal 3 «Ensure healthy lives and promote well-being for all at all ages». According to the World Health Organization (WHO), up to 7 million people die every year because of air pollution; more than $91 \%$ of the world's population live in places where air quality exceeds the WHO guideline limits (WHO, 2018). The main source of pollution is fossil fuels, such as coal, oil, natural gas, that are intensively used to produce energy and as a vehicle fuel. In this paper, the focus is on air pollution emitted from transportation; the authors have examined the examples of using environmentally friendly transport in different cities around the world and analyzed the results of the program for replacing diesel buses with electric buses in Moscow.

\section{Problem Statement}

In modern cities, the abundance of external effects, including economic, social, and environmental externalities is becoming a significant problem (Kudryavtseva et al., 2021). To address externalities it is necessary to focus on the implementation of SDG 11 «Make cities and human settlements inclusive, safe, resilient and sustainable». The sustainable development goals are broken down to specific targets and indicators, particularly in the research (Porfiryev, Bobylev, 2018). In this study, a variety of sub-goals aimed at improving the quality of life of society can be observed: from increasing the availability of affordable housing to preserving the cultural and natural heritage. The most interesting points are 11.2 and 11.5. The former calls for increasing the attractiveness and sustainability of public transport, it is proposed to conduct an assessment using passenger traffic. The latter states the need of reducing environ- mental damage, paying special attention to air quality problems and waste. Among other things, it is proposed to use the volume of particulate matter that has a diameter of less than 2.5 micrometers (PM2.5) as a metric.

During the last decades, economic systems have reached such level of development when the quality of growth takes on a particular importance, reducing the role of the economic growth rates (Zander, Startseva, 2010). The new approach supposes that macroeconomic indicators, such as Gross Domestic Product, cannot be the only measures of real progress of nations and separate territories (Pyzhev et al., 2015). Among integral indices, the US Cities Sustainable Development Goals Index (SDGI) is of special interest (Prakash et al., 2017). It combines 52 indicators of sustainable development and integrates 16 of the 17 SDGs that reflect the income of the population, the state of infrastructure, the level of education and health care, etc. The results show that US cities are far from maximum possible index scores, but medium-sized and large cities have a noticeable advantage over less populated settlements that suggests the need for large investments in urban projects to achieve the Sustainable Development Goals.

Unfortunately, the latter index is not universal because of its specifics and the complexity of calculation. For international comparative studies the City Prosperity Index (CPI), which is an integral index of urban prosperity adopted by the United Nations Development Programme (UNDP), can be used. This metric aggregates indicators of productivity, quality of life, environmental sustainability, the level of infrastructure development and social inequality, aligning them with the relevant SDGs and making it possible to compare the largest cities in the world that have large datasets in these categories. Due to the introduction of the City Prosperity Index it is possible to observe the degree of readiness of metropolises to implement the SDGs and compare the results obtained on large samples of cities.

It is important to mention the work of Russian authors (Bobylev et al., 2014). In their research, they decompose the targets of sustainable development into three components of the 
life of society: economic, social, and environmental. For each component, its own metric is chosen: the level of urbanization in the particular state, the human development index, and the level of solid particles suspended in air (PM10 in $\mu \mathrm{g} / \mathrm{m} 3)$. Rapidly developing countries that still have a low percentage of the urban population (China, India) demonstrate a relatively low level of the human development index and high concentrations of fine particles in the air, which indicates the unsustainable development of cities in these countries. In addition, the authors propose an original method for assessing the sustainability of cities - the index of city sustainability (or the adjusted net savings index), which has the following formula:

$$
A N S=G S+H C B-E D,
$$

where GS is gross savings, HCB stands for the human capital budget, and ED represents the damage caused by the environmental pollution (all components are presented as a percentage of the analogue of the gross regional product for the cities). Logically, higher values of the index correspond with more sustainable development of the city. The paper uses St. Petersburg and Moscow as examples, St. Petersburg demonstrating significantly greater sustainability compared to the capital. The advantage of St. Petersburg is achieved primarily due to considerably higher gross savings and paradoxically greater damage caused by environmental pollution. Perhaps in the future it is worth assigning different weights to different components, since the volume of gross savings may depend on many different parameters, the most plausible of which is a significant difference in the number of migrants moving to the city in search of work.

B. A. Revich in his research identifies priority factors of the urban environment that affect the quality of life: air quality, climate, acoustic risks, and population density (Revich, 2018).

For metropolises, the problem of overpopulation is relevant. It relates to a huge number of jobs in cities that attracts more and more people. The benefits of high-rise buildings, which are especially popular in rapidly developing cities, are overlapped by numerous threats to public health. Higher building density increases the number of private cars and worsens transport and environmental situation. This also leads to acoustic risks associated with the impact of long-term exposure to various noises on human health. Continual noise exposure can cause the diseases of nervous and circulatory systems. The most widely accepted indicator of the quality of life in urban areas is air quality. The above-mentioned SDGs present only one criterion associated with this factor - the content of particulate matter less than 10 microns (PM10) and fine particles less than 2.5 microns (PM2.5) in diameter in the air. It is enough to look at the excess mortality from air pollution caused by PM10 in Moscow to realize the need for minimizing this indicator. There are about 3000 deaths every year, or $2.2 \%$ of the total number of deaths per year (Revich, 2018). According to the WHO, outdoor air pollution accounts for an estimated 4.2 million premature deaths per year (WHO, 2018). The WHO air quality guidelines stipulate that PM10 should not exceed $20 \mu \mathrm{g} / \mathrm{m} 3$, each $10 \mu \mathrm{g} /$ $\mathrm{m} 3$ elevation in fine particulate air pollution is associated with an increase in the mortality by $3 \%$ (WHO, 2006). Moscow, Krasnoyarsk and Rostov-on-Don with PM10 concentration levels of $34 \mu \mathrm{g} / \mathrm{m} 3,51-93 \mu \mathrm{g} / \mathrm{m} 3$ and $53-67 \mu \mathrm{g} /$ $\mathrm{m} 3$ significantly exceed the recommended values (Revich, 2018).

According to the International Energy Agency (IEA, 2016), road transport is the largest source not only of suspended particles, but also of nitrogen oxides - another type of substances harmful to human health $(73 \%$ and $58 \%$, respectively). Exhaust gases, as well as tyre, road surface, and brake wear are the main sources of pollution from road transport. So, minimizing all these types of pollution is a priority when making decisions about the city development.

\section{Literature Review}

In this section the authors analyze the works related to the impact of urban public transport on air pollution.

In (Basagaña et al., 2018) the researchers examine the effect of public transport strikes on air pollution levels in Barcelona in 2005- 
2016. According to the authors, the city-wide concentrations of different types of pollutants are $4 \%-8 \%$ higher during public transport strikes. The increases are even higher during multiday strikes, when citizens change the patterns of transport behavior due to the inability to use public transport, which leads to more severe traffic congestion.

Among other studies that examine the connection between urban public transport and air pollution, (Mulalic, Rouwendal, 2020) is of considerable interest. In this paper, the authors investigate the interaction between an extension of the public transport network and car ownership. It was estimated that an extension of the metro network in Copenhagen reduced the overall car ownership rate by $2-3 \%$. It allowed to relieve many problems (congestion, pollution) associated with the presence of cars in urban areas.

The most significant research on this topic is (Bauernschuster et al., 2017). The authors analyze the data from the five largest German cities and the problems caused by public transport shutdown during labour strikes. They examine the impact of strikes on air pollution, traffic congestion and public health. It is estimated that strikes have a statistically significant effect on morning peak emissions from particulate matter. The results show that PM10 pollution, depending on model specification, increases by $13,3 \%-14,8 \%$ during the AM peak hours of a strike day. According to the authors' observations, this is primarily due to a higher average number of road accidents on days when car traffic is denser than usual, which leads to congestion and, as a result, increased air pollution. In addition, the German researchers found out a statistically significant increase in respiratory diseases among children under 5 years of age and people aged 65 and over as a direct consequence of increased air pollution on strike days.

It can be concluded that creating a stable, sustainable urban public transportation system is necessary, since the adoption of appropriate measures can solve many problems related to the life of the urban population: reducing average travel time, the number of car accidents, the concentration of suspended particles in the atmosphere, respiratory illnesses and concomitant diseases.

In recent years, programs on the ecologization of public transport have appeared in many cities all over the world, including Shenzhen and Helsinki, whose projects have been highly rated by the International Energy Agency. There are some similarities between these two cities and Moscow, which are discussed below.

The Global EV ${ }^{1}$ Outlook (IEA, 2020) discusses the results of transport reforms. One of the reasons for criticizing electric buses operating in Moscow is extremely unecological diesel engines installed to maintain the optimum temperature for efficient engine operation and passengers' comfort in cold weather. The grounds for criticism are the lack of environmental standards for such an installation that can erase ${ }^{2}$ environmental benefits. The report on the reform carried out in Helsinki states the reduction of the costs of using electric buses over time. At the time of conducting the research, these costs do not exceed those of diesel buses. In addition, Helsinki's cold climate is similar to Moscow's, so public transport operators also use auxiliary heating installations at low temperatures, but in Finland's capital environmentally friendly biofuel is used instead of diesel.

Turning to the study on the electrification of the bus fleet in Shenzhen (Berlin et al., 2020), it is important to point out that the reform in this city of China is most similar to the one carried out in Moscow. In both cities the problem of air pollution is severe; more than 12 million people live in each city, the annual passenger traffic volume in ground transportation being above 2 billion people. The project of transitioning to environmentally friendly buses in Shenzhen was carried out in 2009-2017. By the end of 2017, all urban buses in Shenzhen, around 17 thousand buses, were electrified. Local government subsidies supported the fast and full electrification of the bus fleet in the city. Subsidies were directly paid to the bus manufacturers. With the government subsidy the total cost of ownership of the electric bus is $36 \%$ less

\footnotetext{
EV - electric vehicles.

2 Mosgortrans reports that diesel engines in electric buses are used only when the outdoor temperature drops below $5{ }^{\circ} \mathrm{C}$.
} 
than that of a diesel bus over the bus lifetime of 8 years. It is important to mention that both in Shenzhen and Moscow the vast majority of energy used to charge batteries is produced at thermal power plants, so electric buses cannot be regarded as absolutely environmentally friendly. Nevertheless, the researchers note a twofold decrease in total pollutant emissions from the use of electric buses compared to diesel buses of the latest generation.

Apart from the above-mentioned PM2.5 и PM10, the authors focus on such air pollutants as $\mathrm{CO}$ (carbon monoxide), NOx (nitrogen oxides) and $\mathrm{SO} 2$ (sulfur dioxide) in order to evaluate the success of the project (Table 1).

Below we examine the proposed and current measures aimed at improving the quality of life of Moscow citizens and creating a more sustainable future for the city. Since 2010, Moscow's ground and underground transport has been actively transformed. The number of metro stations almost doubled up to 333 stations. The fleet of carriages was upgraded by $58 \%$, the trains became quieter and more comfortable (The official portal of..., 2020). However, much more interesting changes have been happening to the ground transport. While the city trams are following the path of their underground «brothers» upgrading the rolling stock, increasing the capacity and the efficiency of transportation, the fleet of railless transport is undergoing much more interesting changes. Since September 2018, a new type of transport has begun to develop in Moscow - an electric bus. The main feature of this alternative to traditional trolleybuses and diesel buses is an electric engine as an energy source which allows to avoid the use of wires and trolley poles.
It is worth noting that the deployment of electric buses in Moscow is massively criticized. Experts point out their high costs, the loss of time during charging, passengers are concerned that electric buses fail to be on their routes in extremely cold weather and that the number of trolleybuses has significantly reduced. Some of these claims are well grounded: the average cost of an electric bus is 34.1 million rubles compared to 13 million rubles for diesel and gas buses (The Report of Mosgortrans to..., 2019). Another metric given in the Report is the cost per 1 passenger seat. Electric buses lose to classic buses (1.59 rubles against 1.31 rubles), but have an advantage over trolleybuses (1.67 rubles per 1 passenger seat). The full comparative table is below (Table 2).

At the time of publication of this Report, about 300 electric buses were purchased, this number was doubled in 2020, it is planned to purchase 2000 additional electric buses by the end of 2023. Moreover, Moscow Department of Transport announced that it will stop purchasing new diesel buses in 2021. Thus, electric buses will account for $30 \%$ of Moscow's railless ground transport fleet by the end of 2023 (Mosgortrans, 2020). It is logical to assume that an increase in the number of electric buses will reduce the costs, thereby bringing the costs per 1 passenger seat closer to the level of traditional buses.

Despite higher direct costs, electric engines have more environmental and social benefits than their popular alternatives. For example, (Berlin et al., 2020) demonstrates that an environmentally friendly use phase of electric buses allows to eliminate emissions of particulate matter, since electric engines do not pro-

Table 1. Comparison of emissions of 100 kilometers for one diesel and one electric bus (g)

\begin{tabular}{|c|c|c|c|}
\hline Pollutant & Diesel bus & Electric bus & $\begin{array}{c}\text { Emission reduction } \\
\text { after bus electrification }\end{array}$ \\
\hline CO & 116.80 & - & 116.80 \\
\hline NOx & 568.00 & 10.81 & 557.19 \\
\hline PM2.5 & 11.00 & - & 11.00 \\
\hline PM10 & 17.64 & - & 17.64 \\
\hline SO2 & 2.50 & 11.38 & -8.88 \\
\hline
\end{tabular}

Source: Berlin et al. (2020). 
Olga V. Kudryavtseva, Anastasiia V. Baraboshkina... Sustainable Low-Carbon Development of Urban Public Transport...

Table 2. Current costs of different types of public transport in Moscow, December 2019

\begin{tabular}{|l|c|c|c|c|c|}
\hline \multicolumn{1}{|c|}{ Indicator (RUB th., where applicable) } & Electric bus & Diesel bus & Gas bus & Trolleybus & $\begin{array}{c}\text { Low-floor } \\
\text { tram }\end{array}$ \\
\hline Passenger capacity & 85 & 85 & 85 & 85 & 185 \\
\hline RUB per 1 passenger seat & 1.59 & 1.31 & 1.21 & 1.67 & 1.20 \\
\hline Cost of a transport vehicle per unit & 34089.16 & 13173.00 & 13136.51 & 18000.00 & 104348.00 \\
\hline Cost of a battery & 9450.56 & - & - & - & - \\
\hline Maintenance and transport vehicle repair & 2016.04 & 879.60 & 1020.00 & 795.68 & 3466.66 \\
\hline Costs per unit per year & 8113.90 & 6705.89 & 6185.63 & 7115.34 & 14418.51 \\
\hline
\end{tabular}

Source: The Report of Mosgortrans to the Ministry of Transport (2019).

duce combustion products and reduce this kind of emissions caused by tyre and brake wear due to smooth operation.

\section{Data and Methods}

Before starting the description of the details of our research, it is important to point out that in comparison with the papers discussed above, the authors of which either had access to publicly unavailable data (IEA, 2020) or had an opportunity to communicate directly with the authors of the program (Berlin et al., 2020), we were only able to use public data (this, however, facilitates the verification of the results). In addition, the analyzed project is carried out by the Government of Moscow; it is not obliged to provide open access to the project data.

The authors formulated the following hypotheses regarding modeling results:

- Ending the use of diesel buses of the previous generation and transitioning to more environmentally friendly public transport reduce the volume of pollutant emissions in the reforming districts.

- The more electric bus routes are in the district, the stronger the effect is.

The research data were collected from several sources and relevant as of April 19th, 2021. The main sample is the table "Average monthly indicators of air pollution» from the open data portal of the Moscow City Government, which is updated on a monthly basis and contains the information about «values of average monthly concentrations of pollutants in atmospheric air in Moscow, measured by automatic air pollution control stations (AAPCSs)» (Open Data Portal..., 2021). The data include
22 substances measured at 47 AAPCSs since February 2016. For visualization and analysis purposes, the map of Moscow with geotagged AAPCSs was created (Fig. 1).

After grouping the initial 16461 observations by month and the name of the station, 2574 observations were obtained. Then the types of pollutants relevant for the research were identified (they were mentioned in the previous sections of the paper). The description of the final set of variables is presented in (Table 3 ).

The next step in data collection was the integration of the observational data on air pollution into the urban ground transport network. The information about all ground transport routes, as well as the dates of commissioning 45 electric bus routes are available on the official website of SUE «Mosgortrans». After examining the addresses of stations and electric bus routes, an auxiliary table was created. It matches the date of launching an electric bus and the address of an air pollution control station located on its way. We found out that 12 out of 47 AAPCSs in our sample are on the way of at least one electric bus. The described distribution and the number of routes that pass through the districts with air pollution control stations (necessary to test the second hypothesis) are presented in (Table 4).

The final step was the exclusion of the values obtained in April and May 2020 due to the COVID-19 pandemic peak at that time. The basis for this decision was the "Activity on the city streets of the world» indicator presented by Yandex. At that time Moscow citizens' activity did not exceed $30 \%$ of the value of this indica- 


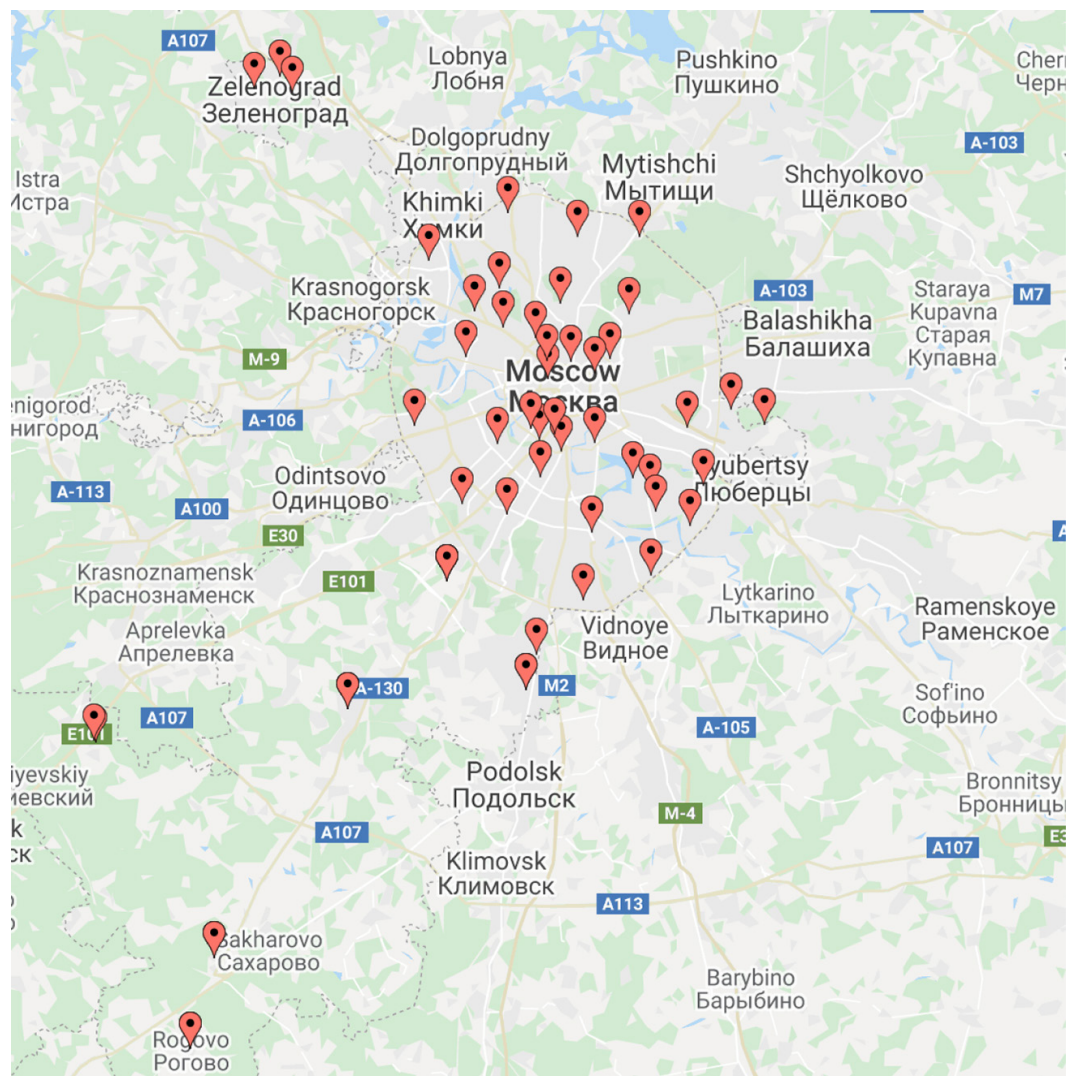

Fig. 1. The map of Moscow with geotagged AAPCSs

(Source: created with BatchGeo on the basis of the data collected by the authors)

Table 3. Description of variables

\begin{tabular}{|c|l|}
\hline Variable name & \\
\hline site & Name of an AAPCS from the Moscow City Government open data portal \\
\hline code & Code word, assigned to each site to facilitate the use of a variable in R \\
\hline PM10 & Monthly average concentration of PM10, $\mu \mathrm{g} / \mathrm{m} 3$ \\
\hline PM2.5 & Monthly average concentration of PM2.5, $\mu \mathrm{g} / \mathrm{m} 3$ \\
\hline CO & Monthly average concentration of carbon monoxide, $\mathrm{mg} / \mathrm{m} 3$ \\
\hline NO2 & Monthly average concentration of nitrogen dioxide, $\mu \mathrm{g} / \mathrm{m} 3$ \\
\hline district & $\begin{array}{l}\text { Name of a district, where the AAPCS from the Mos- } \\
\text { cow City Government open data portal is installed }\end{array}$ \\
\hline treatment & $\begin{array}{l}\text { Binary variable equal to 1, if in a given month there is at } \\
\text { least one electric bus route in the district }\end{array}$ \\
\hline month_year & $\begin{array}{l}\text { Variable responsible for the belonging of an observation to a par- } \\
\text { ticular month and year. It is used to control time effects. }\end{array}$ \\
\hline
\end{tabular}

Source: compiled by the authors on the basis of collected data. 
Table 4. Electric bus routes and AAPCSs

\begin{tabular}{|c|c|c|c|c|c|}
\hline Station code & Moscow district & $\begin{array}{l}\text { The date } \\
\text { of launching } \\
\text { an electric bus }\end{array}$ & $\begin{array}{c}\text { Name } \\
\text { of a station }\end{array}$ & Address of an AAPCS & $\begin{array}{l}\text { Number } \\
\text { of routes }\end{array}$ \\
\hline ostankino & $\begin{array}{l}\text { Ostankinsky } \\
\text { District }\end{array}$ & $12 / 03 / 2019$ & Ostankino 0 & $\begin{array}{l}\text { Ulitsa Akademi- } \\
\text { ka Koroleva, 15A }\end{array}$ & 8 \\
\hline $\mathrm{mgu}$ & Ramenki District & 05/11/2019 & MGU & Leninskie Gory, 1, stroenie 27 & 7 \\
\hline tolbukhina & $\begin{array}{l}\text { Mozhaysky } \\
\text { District }\end{array}$ & $15 / 06 / 2020$ & Tolbukhina & $\begin{array}{l}\text { Ulitsa Tolbukhi- } \\
\text { na, } 10, \text { korpus } 4\end{array}$ & 5 \\
\hline chayanova & Tverskoy District & 29/09/2019 & Chayanova & $\begin{array}{c}\text { 4-ya Tverskaya- } \\
\text { Yamskaya ulitsa, 26/8 }\end{array}$ & 4 \\
\hline kazakova & $\begin{array}{l}\text { Basmanny } \\
\text { District }\end{array}$ & 06/03/2019 & Kazakova & $\begin{array}{l}\text { Gorokhovskii pereu- } \\
\text { lok, 4, korpus 1A }\end{array}$ & 3 \\
\hline spartak & $\begin{array}{l}\text { Basmanny } \\
\text { District }\end{array}$ & $15 / 07 / 2019$ & $\begin{array}{c}\text { Spartakovskaya } \\
\text { ploshchad }\end{array}$ & Bakuninskaya ulitsa, 23-41 & 3 \\
\hline opolcheniya & $\begin{array}{c}\text { Khoroshevo- } \\
\text { Mnevniki } \\
\text { District }\end{array}$ & $23 / 06 / 2020$ & $\begin{array}{l}\text { Narodnogo } \\
\text { opolcheniya }\end{array}$ & $\begin{array}{l}\text { Ulitsa Narodnogo opol- } \\
\text { cheniya, 21, korpus } 1\end{array}$ & 2 \\
\hline gagarina & Donskoy District & $06 / 05 / 2020$ & $\begin{array}{c}\text { Ploshchad } \\
\text { Gagarina }\end{array}$ & Leninsky prospekt, 30 & 2 \\
\hline $\begin{array}{l}\text { dolgoprud- } \\
\text { naya }\end{array}$ & $\begin{array}{l}\text { Dmitrovsky } \\
\text { District }\end{array}$ & $12 / 03 / 2019$ & Dolgoprudnaya & Karelsky bulvar, 14/16 & 1 \\
\hline maslovka & $\begin{array}{l}\text { Savyolovsky } \\
\text { District }\end{array}$ & 09/09/2019 & $\begin{array}{l}\text { Nizhnyaya } \\
\text { Maslovka }\end{array}$ & $\begin{array}{l}\text { Ulitsa Nizhnyaya } \\
\text { Maslovka, } 10\end{array}$ & 1 \\
\hline ostrov & $\begin{array}{l}\text { Metrogoro- } \\
\text { dok District }\end{array}$ & $15 / 07 / 2019$ & $\begin{array}{l}\text { Losiny } \\
\text { Ostrov }\end{array}$ & Ulitsa Roterta, 4, stroenie 5 & 1 \\
\hline anokhina & $\begin{array}{c}\text { Troparyovo- } \\
\text { Nikulino District }\end{array}$ & 05/11/2019 & $\begin{array}{l}\text { Akademika } \\
\text { Anokhina }\end{array}$ & $\begin{array}{c}\text { Ulitsa Akademika } \\
\text { Anokhina, 38, korpus } 1\end{array}$ & 1 \\
\hline
\end{tabular}

Source: compiled by the authors using data from Mosgortrans.

Table 5. Descriptive statistics of variables

\begin{tabular}{|c|c|c|c|c|c|}
\hline Variable & $\mathrm{N}$ & Mean & St. Dev. & Min. & Max. \\
\hline PM10 & 849 & 22,155 & 11,016 & 4,000 & 90,000 \\
\hline PM2.5 & 638 & 10,886 & 3,668 & 2,000 & 27,000 \\
\hline SO2 & 945 & 3,021 & 2,937 & 0,000 & 67,900 \\
\hline CO & 2284 & 0,342 & 0,152 & 0,020 & 1,260 \\
\hline NO2 & 2145 & 32,911 & 13,846 & 2,100 & 89,400 \\
\hline treatment & 2482 & 0,070 & 0,255 & 0 & 1 \\
\hline
\end{tabular}

Source: compiled by the authors

tor before the pandemic. Finally, the following data set was prepared (Table 5).

To test the first hypothesis about the positive impact of the environmentally friendly public transport on air pollution, a bidirectional model with fixed effects is used. Using such a specification is appropriate, since it takes into account both individual effects and time effects. The regression has the following form:

$$
\begin{aligned}
& \log \left(\text { Pollutant }_{i t}\right)=\beta_{0}+\beta_{1} \cdot \text { treatment }_{i t}{ }^{+} \\
& +\overline{\beta_{3}} \cdot \overline{\text { site }}+\overline{\beta_{4}} \cdot \overline{\text { month_year }}
\end{aligned}
$$


where

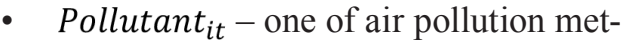
rics available to us for each AAPCS $i$ in each observed month $t$;

- treatment $_{i t}$ - binary variable equal to 1 if there is an electric bus route next to AAPCS $i$ in month $t$;

- $\overline{\text { site }}$ - vector of binary variables that controls the effects of relating to one or another AAPCS;

- $\overline{\text { month_year }}$ - vector of binary variables that controls the existence of time trends and seasonality.

We use the logarithm of the dependent variable in order to facilitate the interpretation of modeling results, as there are some difficulties, including different dimensions of pollutants. While working with panel data, it is necessary to address heteroscedasticity using robust standard errors (HAC1). Table 6 shows the results of evaluating the effect of five pollutants mentioned earlier (Table 6).

\section{Results and Discussion}

The results show that only for carbon monoxide (model specification (1)) there is an effect significant at the 0.1 level, which means the reduction of monthly average concentration of $\mathrm{CO}$ in the air by $10.8 \%$ for the districts where there are electric bus routes.

We used an empirical strategy to assess the impact of electric vehicles on different types of pollutants. As a result, we found out that the expected effect is not observed for all pollutants. There are several reasons for this:

- Large data gaps that cause limited sampling. It is important to point out that in many districts electric buses were launched only this year.

- A small number of electric buses $(600$ e-buses as of the end of 2020 - less than $10 \%$ of the total bus fleet in Moscow) that represent an insignificant share in the traffic flow, which is dominated by private cars with traditional energy sources, especially in busy areas.

The short horizon of available data and the early stage of the project make the analysis of its effectiveness very difficult. However, below an alternative graph-analytical approach to assess the effect of the reform is also proposed.

The above Table 4 demonstrates the number of electric bus routes passing through the districts where automatic air pollution control stations (AAPCSs) are installed. Among them, the one with the code name ostankino («Ostankino 0 » in the database of the open data portal) deserves particular attention, since there are 8 electric bus routes (Table 7).

The authors identified several interesting patterns (Fig. 2):

- Over time, after the implementation of the environmentally friendly public transport program, cyclical peaks in the level of air pollution have been decreasing; for example, sum-

Table 6. Results of the evaluation of the equation for the pollutants

\begin{tabular}{|l|c|c|c|c|c|}
\hline \multirow{2}{*}{} & \multicolumn{5}{|c|}{ Dependent variable } \\
\cline { 2 - 6 } & $\begin{array}{c}\log (\mathrm{CO}) \\
(1)\end{array}$ & $\begin{array}{c}\log (\mathrm{NO} 2) \\
(2)\end{array}$ & $\begin{array}{c}\log (\mathrm{PM} 2.5) \\
(3)\end{array}$ & $\begin{array}{c}\log (\mathrm{PM} 10) \\
(4)\end{array}$ & $\begin{array}{c}\log (\mathrm{SO} 2) \\
(5)\end{array}$ \\
\hline Treatment & $\begin{array}{c}-0,115^{*} \\
(0,070)\end{array}$ & $\begin{array}{c}0,046 \\
(0,090)\end{array}$ & $\begin{array}{c}-0,215 \\
(0,142)\end{array}$ & $\begin{array}{c}-0,012 \\
(0,109)\end{array}$ & $\begin{array}{c}-0,081 \\
(0,184)\end{array}$ \\
\hline Time effects & Yes & Yes & Yes & Yes & Yes \\
\hline $\begin{array}{l}\text { Individual effects of the control } \\
\text { stations }\end{array}$ & Yes & Yes & Yes & Yes & Yes \\
\hline The number of observations & 2284 & 2145 & 638 & 849 & 944 \\
\hline R-squared & 0,005 & 0,001 & 0,020 & 0,0001 & 0,001 \\
\hline F-statistic & $\begin{array}{c}11.447 * * * \\
(\mathrm{df}=1 ; 2179)\end{array}$ & $\begin{array}{c}2.191 \\
(\mathrm{df}=1 ; 2040)\end{array}$ & $\begin{array}{c}11.074 * * * \\
(\mathrm{df}=1 ; 555)\end{array}$ & $\begin{array}{c}0.108 \\
(\mathrm{df}=1 ; 771)\end{array}$ & $\begin{array}{c}1.060 \\
(\mathrm{df}=1 ; 860)\end{array}$ \\
\hline
\end{tabular}

Source: compiled by the authors.

Note: 1 ) $\left.{ }^{*} p<0,1 ;{ }^{* *} p<0,05 ;{ }^{* * *} p<0,01 ; 2\right)$ in brackets - robust standard errors (HC1) 
Table 7. The extension of an electric bus network in Ostankinsky District

\begin{tabular}{|c|c|}
\hline Route & The date of transitioning to electric buses \\
\hline T36 & $12 / 03 / 2019$ \\
\hline T73 & $30 / 03 / 2019$ \\
\hline T76 & $15 / 07 / 2019$ \\
\hline 76 & $15 / 07 / 2019$ \\
\hline 93 & $25 / 03 / 2020$ \\
\hline T13 & $28 / 11 / 2020$ \\
\hline 154 & $18 / 03 / 2021$ \\
\hline 803 & $18 / 03 / 2021$ \\
\hline
\end{tabular}

Source: compiled by the authors using the data from Mosgortrans.

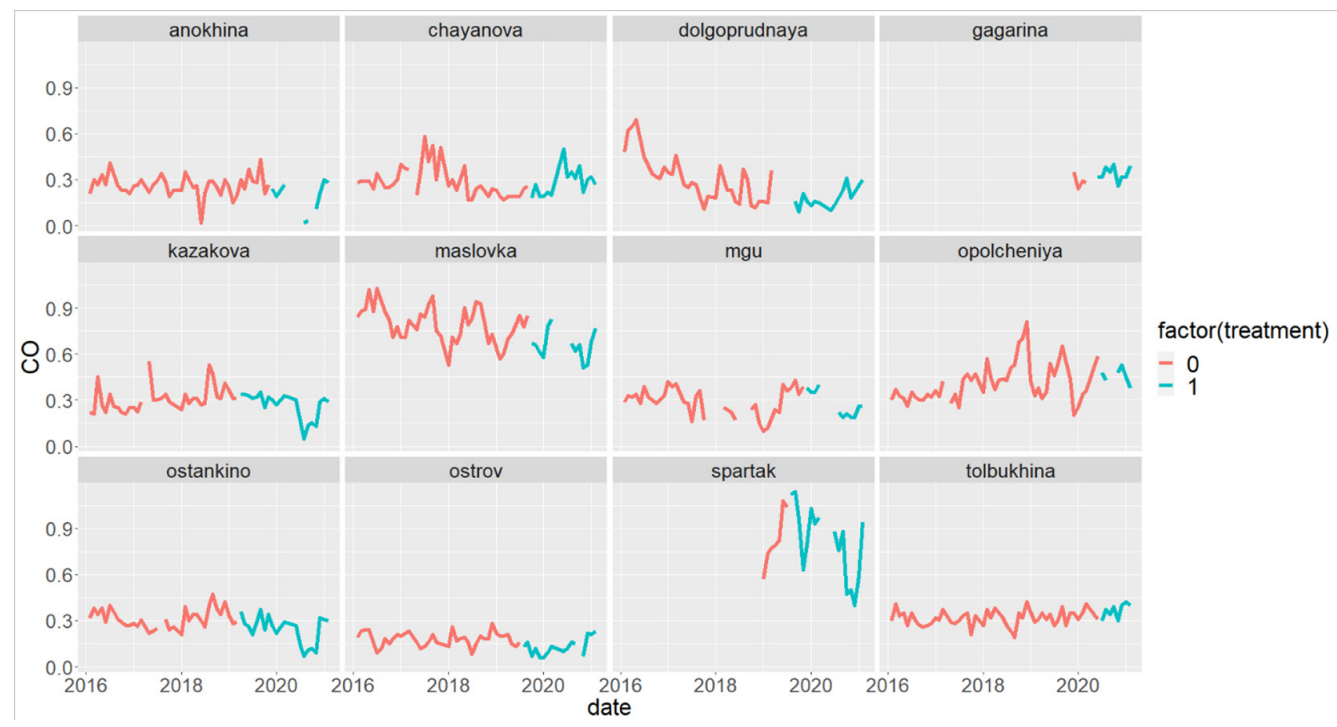

Fig.2 The dynamics of CO pollution in the observed districts (Source: compiled by the authors)

mer and spring cycles had significantly lower peaks in the observed zones of kazakova, ostankino, maslovka after 2018.

- In the ostankino zone, a decrease in the average levels of $\mathrm{CO}$ pollution measured by the AAPCS occurred after the launch of the first electric buses. It had been continuing to decrease with an increase in the number of electric bus routes in the district until the seasonal winter peak at the end of 2020 .

- The more electric buses routes pass near AAPCSs, the stronger the described effect is.

It can be concluded that the availability of detailed data for the analysis is limited.
Nevertheless, we have identified positive aspects of using electric buses instead of traditional ones. Thus, we can talk about the partial confirmation of the second hypothesis. At the same time, more time is needed to confirm the efficiency of the project and test the first hypothesis, as the current number of electric bus routes is quite small. Moreover, the expected real effect of launching electric buses in Moscow may not be so significant, and positive trends in air pollution can also be related to the overall annual decrease in urban air pollution described in (Revich, 2018). 


\section{Conclusion}

The quality of life in a modern city is directly related to the quality of public transport, its environmental friendliness playing an important role. We consider the project of integrating electric buses into Moscow's transport system as a step towards the low-carbon development of this industry. A significant effect was identified for carbon monoxide emissions. It should be noted that the project is currently at an early stage of its implementation. Moreover, the num- ber of automatic air pollution control stations is not enough. Moscow, the largest city in Europe, has limited data on air pollution: control stations (AAPCS) are installed only in 43 out of 125 districts of the city. For further research, it is necessary to add control variables, including traffic congestion and climate variables. This topic has a great potential for further study. The network of electric buses is expanding, which makes it possible to assess the socio-economic effects after obtaining new data.

\section{References}

«Activity on the city streets of the world» (2020). Available at: https://yandex.ru/maps/covid19/isolation? $11=41.775580 \% 2 \mathrm{C} 54.894027 \& \mathrm{z}=3$ (accessed 23 June 2021).

Basagaña, X., Triguero-Mas, M., Agis, D., Pérez, N., Reche, C., Alastuey, A., Querol, X. (2018). Effect of public transport strikes on air pollution levels in Barcelona (Spain), In Science of the Total Environment, 610-611, 1076-1082. DOI: 10.1016/j.scitotenv.2017.07.263

Bauernschuster, S., Hener, T., Rainer, H. (2017). When labor disputes bring cities to a standstill: The impact of public transit strikes on traffic, accidents, air pollution, and health, In American Economic Journal: Economic Policy, 9 (1), 1-37. DOI: 10.1257/pol.20150414

Berlin, A., Zhang, X., Chen, Y. (2020). Case Study: Electric buses in Shenzhen, China, In World Bank.

Bobylev, S.N., Kudryavtseva, O.V., Solovyeva, S.V. (2014). Indikatory ustoichivogo razvitiia dlia gorodov [Sustainable development indicators for cities], In Ekonomika regiona [Economy of Region], 3, 101-110. DOI: $10.17059 / 2014-3-9$

IEA (2016). World Energy Outlook 2016. Paris, 684 p.

IEA (2020). Global EV Outlook 2020. Paris, 276 p.

Kudryavtseva, O.V., Malikova, O.I., Egorov, E.G. (2021). Sustainable Urban Development and Ecological Externalities: Russian Case, In Geography, Environment, Sustainability, 14 (1), 81-90. DOI: 10.24057/2071-9388-2020-15

Mosgortrans (2021). Available at: https://mosgortrans.ru (accessed 11 July 2021).

Mulalic, I., Rouwendal, J. (2020). Does improving public transport decrease car ownership? Evidence from a residential sorting model for the Copenhagen metropolitan area, In Regional Science and Urban Economics, 83, 1035-1043. DOI: 10.1016/j.regsciurbeco.2020.103543

Open Data Portal of the Moscow City Government (2021). Available at: https://data.mos.ru/ (accessed 15 July 2021).

Porfiryev, B.N., Bobylev, S.N. (2018). Cities and Megalopolises: The Problem of Definitions and Sustainable Development Indicators, In Studies on Russian Economic Development, 29, 116-123. DOI: 10.1134/ S1075700718020119

Prakash, M., Teksoz, K., Espey, J., Sachs, J., Shank, V. (2017). The U. S. Cities Sustainable Development Goals Index, In SDSN Working Paper.

Pyzhev, A.I., Syrtsova, E.A., Pyzheva, Y.I., Zander, E.V. (2015). Sustainable Development of Krasnoyarsk Krai: New Estimates, In Journal of Siberian Federal University. Humanities \& Social Sciences, 8, 2590-2595. DOI: 10.17516/1997-1370-2015-8-11-2590-2595.

Revich, B.A. (2018). Prioritetnye faktory gorodskoi sredy, vliiaiushchie na kachestvo zhizni naseleniia megapolisov [Priority Factors in Urban Environments That Affect the Quality of Life for Metropolitan Populations], In Studies on Russian Economic Development, 29 (3), 267-273. DOI: 10.1134/S1075700718030115

The official portal of the Moscow Mayor and Moscow Government (2020). Available at: https://www. mos.ru/city/projects/metro85/ (accessed 17 June 2021). 
The Report of Mosgortrans to the Ministry of Transport (2019). Available at: https://baza.io/ posts/715f645d-1d7c-4375-b359-cf1b58e72308 (accessed 25 June 2021).

UN (2015). Transforming Our World: the 2030 Agenda for Sustainable Development. New York, 41 p. WHO (2006). Air Quality Guidelines Global Update 2005. Copenhagen, 496 p.

WHO (2018). Available at: https://www.who.int/news-room/fact-sheets/detail/ambient-(outdoor)-airquality-and-health (accessed 20 June 2021).

Zander, E.V., Startseva, Y.I. (2010). Ecological Balance of Territory: Key Factors and the Regulation Mechanism, In Journal of Siberian Federal University. Humanities \& Social Sciences, 3, 962-968. 